\title{
Poland's policy towards membership in the Economic and Monetary Union
}

\begin{abstract}
Poland's accession to the European Union determines future membership in the Economic and Monetary Union (EMU). The subject of the research is the analysis of Polish policy towards EMU membership during the first 15 years of Poland's membership in the EU. The research is political nature and intentionally does not focus on the economic benefits and challenges associated with Poland's membership in the EMU.

The aim of research is to focus on changes taking place in the policy towards Poland's membership in the EMU conducted by the ruling parties, successively by the coalition of the Civic Platform (PO) and the Polish People's Party (PSL) - PO-PSL in years 2007-2015 and then by the Law and Justice (PiS) in years 2005-2007 in consultation with the Self-Defence (Samoobrona RP) and the League of Polish Families (LPR) as well as 2015-2019 in the coalition with the Jarosław Gowin's Agreement (Porozumienie Jarosława Gowina) and Zbigniew Ziobro's Solidary Poland (Solidarna Polska).

The main research questions relate to how has Poland's membership in the EMU been perceived by the ruling parties since 2004 and what are the reasons for the fact that joining the eurozone by Poland until recently had been the strategic goal of the ruling elite of the country, and nowadays the strategic goal has become non-entry into the EMU.

The main research methods were the analysis of the content of documents and a comparative method. The first method allowed presenting the perspective of Poland's entry into the euro area from the side of the ruling parties policy. That is why the text was mainly based on source materials, i.e. reports, government documents, political speeches, party election programs and press articles. The second research method allowed to compare the concept of Poland's membership in the EMU presented in various programs of the ruling political parties.

The result of the conducted research indicates the radicalisation of the views of the Polish political scene. It also proves that date of adoption of the single European currency depends not only on meeting the convergence criteria, but also on which political option will rule in Poland.
\end{abstract}

Key words: polish political parties and euro, EMU membership, radicalisation

\section{Introduction}

$\mathbf{T}$ he finalization of Poland's accession negotiations with the European Union (EU) coincided with the introduction of the euro currency into cash circulation which started in 2002. This fact naturally sparked discussion on the date and potential scenario of becoming by Poland a member of the Economic and Monetary Union (EMU). During the multiple-years' discourse, many potential dates for adopting by Poland the euro were mentioned, e.g. in 2006 (Grzegorz Kołodko, then Minister of Finance), 2008 (Hanna Gronkiewicz-Waltz, former president of the Polish Central Bank (NBP)), 2009 (Mirosław Gronicki, then Minister of Finance), 2012 (Jacek Rostowski, then Minister of Finance), 2015 (Bronisław Komorowski, then President of the Republic of Poland). 
A very original concept was also raised (in 2001) regarding the method of adopting by Poland the euro in the form of unilateral euroization proposed by Jacek Rostowski and Andrzej Bratkowski.

The requirement to join the Economic and Monetary Union was approved by Poland first by signing the Copenhagen criteria in 1993 and then in the Accession Treaty in 2003, which is why the ongoing discussion was not aimed at answering the question whether to join the eurozone, but to answer the question when to join it and according to what scenario. Today, however, after 15 years of the EU membership, there is a noticeable tendency to ask questions about the legitimacy of adopting the single currency from the point of view of the Polish raison d'etat. This tendency was the reason for choosing the issues discussed in this article. It is extremely important because it will determine Polish European policy in the near future as well as Poland's place in the European Union. The significance of the problem is emphasized by the fact that the current discussion on the inclusion of Poland in the EMU takes place according to the internal political division of Poland. The decision to adopt the single currency will depend on which political forces will rule in Poland, the one that is conducive to deepening Poland's membership in the EU structures, or the opposite one.

The purpose of the article is to analyze Poland's policy towards EMU membership during the first 15 years of Poland's membership in the EU. The main research assumption constitutes the hypothesis that as the radicalization of views on the Polish political scene is increasing, the prospects for Poland's joining the EMU is drifting away. In order to verify the above hypothesis, the following research questions were asked: how has Poland's membership in the EMU been perceived by the ruling parties since 2004 and what are the reasons for the fact that joining the eurozone by Poland until recently had been the strategic goal of the ruling elite of the country, and nowadays the strategic goal has become non-entry into the EMU.

The structure of the article was subordinated to that specific purpose, and its content was divided into three parts. The first part presents the determinants of the discussions regarding Poland's membership in the EMU. The second and the third parts focus on the policy towards Poland's membership in the EMU conducted by the ruling parties, successively by the coalition of the Civic Platform (PO) and the Polish People's Party (PSL) - PO-PSL in years 2007-2015 and then by the Law and Justice (PiS) in years 2005-2007 in consultation with the Self-Defence (Samoobrona RP) and the League of Polish Families (LPR) as well as 2015-2019 in the coalition with the Jarosław Gowin's Agreement (Porozumienie Jarosława Gowina) and Zbigniew Ziobro's Solidary Poland (Solidarna Polska). Due to the short time of Marek Belka's rule, the policy of the coalition of the Democratic Left Alliance (SLD) and the Labour Union (UP) towards Poland's entry into EMU does not constitute a separate part of the article. It is merely mentioned in the second part.

The analysis used in the article is of a political nature, which is why the text does not focus on the benefits and economic challenges associated with Poland's membership in the EMU. The economic thread was also raised in many publications and would not bring anything new to the current state of research. The issue of convergence criteria and potential possibilities of meeting them by Poland is not addressed deliberately. The choice of the political science analysis is justified by the lack of literature presenting the 
perspective of Poland's entry into the eurozone from the perspective of the ruling parties' policy. That is why the article was mainly based on source materials, i.e. reports, government documents, political speeches, party election programs and press articles.

In the research analysis, the methods characteristic for social sciences were used, including the analysis of documents' content and the comparative method.

\section{Determinants of Poland's policy towards membership in the Economic and Monetary Union}

Starting its efforts to join the European Union, Poland accepted the conditions set for membership candidates. In addition to the obvious requirement related to the acceptance of the acquis communautaire, they concerned, firstly, the stability of institutions guaranteeing democracy, the rule of law, respect for human rights as well as respect for and protection of the rights of national minorities; secondly, the functioning of the market economy and the country's capacity to face Union market forces; and thirdly, the ability to accept the obligations resulting from the membership, including identification with the goals of political, economic and monetary union. ${ }^{1}$ The last condition from the group of the so-called Copenhagen criteria meant that Poland had to take into account the fact that the natural consequence of the membership in the European Union would be accession to the Economic and Monetary Union. This, in turn, was associated with the need of treating by Poland the convergence criteria as the basic determinants of the country's macroeconomic policy. For the EU itself, the defining of the third criterion constituted a guarantee that the new countries would not apply, following the example of Great Britain and Denmark, for an opt-out clause allowing for non-participation in the EMU and that all of them would gradually join the so-called eurozone.

During the accession negotiations, Poland declared the future adoption of the single currency, and that it would treat the convergence criteria in the medium term as a factor contributing to the proper development of the economy. In the negotiating position in the area of "the Economic and Monetary Union" Poland expressed its readiness to adopt European law in this field by December 31, 2002, while not reporting negotiation problems and not requesting transition periods.

At this time, the discussion on the membership in the EMU began to take shape in Poland. Its beginning was not very successful, because it provided for unilateral euroization, consisting in the fastest possible (before Poland's accession to EMU and even the European Union) replacement of the zloty by the euro, at the exchange rate chosen by the Polish government. The authors of the idea were Jacek Rostowski and Andrzej Bratkowski, who believed that high foreign currency reserves would be used to purchase banknotes and coins of the common currency. In this way, the single currency of the European Union would also become a means of payment in Poland, thanks to which our country would be protected against a currency crisis, as the zloty would no longer be subject to speculative attacks. A. Bratkowski and J. Rostowski also proposed that after the accession to the European Union all new countries should advocate adjusting

1 The criteria were set by the European Council at the Copenhagen Summit in June 1993. For more see: eur-lex.europa.eu/summary/glossary/accession_criteria_copenhague.html?locale=en, 19.07.2019. 
the inflation criterion, so that it only applies to inflation of goods that are the subject of international trade. In their opinion, due to the so-called Harrold-Balassa-Samuelson effect new member states would not be able to meet the inflation criterion for a long time (Bratkowski, Rostowski, 2001, pp. 44-55). Euroization was not accepted, on the contrary, it was criticized by the European Union. The contemporary vice president of the European Central Bank (ECB), Christian Noyer, said in January 2001 that the new countries entering the eurozone would be subject to the same criteria as the original EMU members, as they are included in the Maastricht Treaty. This assumption was in line with the treaties and with the principle of equal treatment of Union members, present and future ones. Although the proposal of unilateral euroization did not find supporters in the government circles and among Polish monetary authorities, it may be considered that it initiated the discussion on the choice of exchange rate policy in connection with Poland's accession to the EMU. At that time, the rigid connection of the zloty-euro exchange rate in the form of the so-called currency board was described and discussed by such economists as, among others, Grzegorz Kołodko, Karol Lutkowski and Stanisław Gomułka. ${ }^{2}$ The first of them, then acting as the Minister of Finance, addressed this topic most cautiously, arguing that the currency board system could be introduced, "if the exchange rate policy that has been pursued so far will not guarantee sufficient progress in improving the competitiveness of Polish enterprises" (Maciejewicz, 2002). The deliberations were ended by the declaration by Leszek Balcerowicz, then the President of the NBP, who announced in October 2002 that the central bank did not intend to depart from the floating exchange rate (introduced in Poland on April 12, 2000), recognizing it as the most relevant exchange rate at the stage of heading towards the EMU.

Poland's membership in the European Union started on May 1, 2004 and formally opened for Poland the door to the EMU. Poland has started participation in the third stage of the EMU as a country subject to derogation. This means that it was required to cooperate within the EMU to the extent specified for countries outside the eurozone and to adopt the single currency once the convergence criteria are met. The date of joining the EMU member states is dependent on the decision of the Polish authorities, as the pace of macroeconomic adjustments and meeting the conditions for adopting euro depends on the specific candidate country, in this case on Poland.

\section{Poland's policy towards membership in the EMU during the rule of the PO-PSL coalition}

The PO-PSL coalition was ruling the country starting from November 2007 till November 2015. At that time, the approach initiated by the Marek Belka government (July 2004-October 2005) was continued, according to which Poland's membership in the EMU was treated as a strategic goal, bringing more benefits than losses. Therefore, it

${ }^{2}$ For more on see: K. Lutkowski, In Search of the Optimal Strategy for Poland on the Road to Euro, "Bank i Kredyt" 2001, no. 11-12; S. Gomułka, Euro instead of zloty, "Wprost" 2001, no. 44, www.wprost.pl, 17.07.2019; J. Rosiek, Controversies regarding the nature of exchange rate policy in the aspect of Poland's accession to the European Monetary Union, "Prace Naukowe" 2006, University of Economics in Katowice, pp. 291-299. 
was recommended to create conditions enabling the fastest possible entry into the eurozone. In this spirit, the first NBP report on Poland's accession to the EMU was drafted in February 2004. It was entitled „Report on the benefits and costs of Poland's accession to the eurozone." Another document was published in August 2005 by the Ministry of Finance headed by Mirosław Gronicki and was entitled ,Integration of Poland with the eurozone: membership conditions and process management strategy."

The newly elected Prime Minister, Donald Tusk, in his exposé in the Sejm on November 23, 2007 stressed that the adoption of the single currency will constitute the crowning achievement of the efforts to restore the economy's stability and ability to grow quickly, which is why Poland should be prepared for this as soon as possible. He did not give the date of Poland's potential accession to the EMU, arguing that the ruling team will not stick to any doctrine, but will be guided by common sense and the security of the economy and ordinary citizens (Tusk, 2007).

Opening the 18th Economic Forum in Krynica in September 2008, Prime Minister Tusk announced, however, that the government's goal would be Poland's accession to the EMU in 2011. The fact that the declaration was not empty-wording, but the result of preparations, may be confirmed by the adoption by the Council of Ministers on October 28, 2009 ,"The Road Map of the adoption by Poland the euro," presenting the order of necessary activities related to entering into the eurozone. At the time of the publication of the said document, Poland was meeting all convergence criteria except for membership in the ERM II mechanism as well as the compliance of national law with the statute of the European System of Central Banks (ESCB) and the European Central Bank. In this situation, the adopted map focused on classic activities that approximated Poland's accession to the ERM II, i.e. changes in national legislation and preparation of the financial system and citizens for the exchange of currency. The solutions adopted by Poland were modelled on the experiences of the states that had previously joined the EMU and went through similar stages.

In October 2008, the stage of Poland's preparations for joining the eurozone was opened by works aimed at including zloty in the ERM II mechanism, culminating in Poland's accession to the exchange rate stabilization mechanism in January 2009. The first stage was also designed to include, among others, development of the National Plan of Introducing the Euro and starting the procedure to amend the Polish constitution. The second stage was to last from January 2009 till the end of 2011. In this two-year period, it was anticipated that the ECOFIN Council would decide to abrogate the derogation towards Poland and set an irrevocable exchange rate of the zloty to the euro. It was also planned to launch an extensive information campaign, produce euro coins with the Polish national side on them, and prepare all institutions and citizens to adopt the new currency (the requirement to provide double prices in zloty and euro). On January 1, 2012, Poland was to join the eurozone and introduce into circulation relevant banknotes and coins. The authors of the document did not specify how long the time of dual circulation of currencies (zloty and euro) would last, after which the zloty would cease to constitute a means of payment. The period of free exchange of Polish banknotes and coins into euro by the NBP was also left to be determined in the future. However, it was recommended to extend the period of applying double prices for 6 months after the introduction of euro (Road Map, 2008, pp. 5-7). 
The natural consequence of the adopted Road Map was the establishment of institutional structures responsible for the comprehensive works on preparing Poland for the adoption of the euro. They were composed of: operating from January 13, 2009, the Government's Representative for introduction of the euro by the Republic of Poland and operating from November 3, 2009, the National Coordination Committee for the euro, the Coordination Council and the Interinstitutional Working Team for the preparation of the introduction of the euro by the Republic of Poland. ${ }^{3}$ A special place in the aforementioned structure was taken by the NBP which, as an institution, was not part of the structure due to the requirement of the bank's independence. Nevertheless, the Cochairman of the Committee was the Representative of the NBP Management Board for issues related to the introduction of the euro, thus having a real impact on the decisions taken in the field Poland's preparation for participation in the EMU.

The ambitious assumptions of the PO-PSL coalition were verified by the crisis in the eurozone, which from the financial crisis evolved into a debt crisis revealing the high public debt of several eurozone member countries and the economic stagnation of the EMU. Poland was also affected by the turmoil in the global market, which took place at the key moment in the announced Road Map, i.e. at the beginning of the preparations for entering by the zloty the ERM II mechanism. At the end of 2008 and in the first half of 2009, there was a significant increase in fluctuations in zloty exchange rate, which negatively affected the condition of entering by Poland the ERM II and setting the central exchange rate into the euro at a level safe for the economy and maintaining it within $+/-15 \% .{ }^{4}$ The cost of buying for in exchange for the zloty the most important currencies - the euro, the dollar and the Swiss franc - increased by several dozen percent (by over $40 \%, 70 \%$ and $50 \%$ respectively). The zloty joined the group of the weakest and most volatile European currencies ("Wprost", 2009). In such a situation, the government's activities focused on defending the value of the Polish currency, even forcing the authorities to apply to the International Monetary Fund (IMF) for funds under the so-called Flexible Credit Line (FCL), whose main task was to support states in fighting crisis situations effectively (Kołodziejczyk, 2012, pp. 123-139).

In connection with the real and costly threat of failure to meet the obligations arising from membership in the ERM II mechanism, the Polish government has re-evaluated its position on entering the eurozone. It did not deviate from the adopted goal, but slightly modified its strategy, whose main assumptions were presented in the document entitled „Determinants of the implementation of subsequent stages of the Road Map of the adoption by Poland the euro" from April 2009. Among the key conditions for starting the implementation of the Road Map, the need to reduce the frequency of the zloty exchange rate fluctuations was mentioned, so that the safe integration of zloty into the ERM II

${ }^{3}$ More on the structure and competences of the appointed bodies in: Journal of Laws 2009, No. 11, item 60 and Journal of Laws of 2009, No. 195, item 1505.

${ }^{4}$ The first signals that zloty was unstable in connection with the possibility of joining the ERM II appeared shortly after D. Tusk's statement in Krynica starting the 18th Economic Forum, announcing adoption by Poland of the single currency in 2011. According to bankier.pl (the article from of 10.09.2018, The government's goal is to enter the eurozone in 2011) - before D. Tusk's statement, the euro exchange rate was 3.4730/3.4750, and within five minutes the rate fell to 3.3950/3.3970 - which is almost PLN 0.08 . 
mechanism was realistic (Michalczyk, 2013). ${ }^{5}$ The emphasis was also put on the necessity of the prior (to the ERM II membership) amendment of the Polish Constitution to achieve greater stability of currency, although membership in the ERM II does not require such a change. It was argued that the lack of a clear perspective for the required legislative adjustments only increases the uncertainty as to meeting the conditions for joining the eurozone and further weakens the zloty (Determinants, 2009).

In practice, this meant that the implementation of the first point of the Road Map (Poland's preparation for entering the ERM II) was postponed, and thus the date of adopting euro was postponed, as well. In the document entitled The Strategic Framework of the National Plan for Introduction of the Euro of October 26, 2010, the government clearly signalled that the inclusion of the zloty in the exchange rate mechanism should occur when there is a high probability of lasting compliance within the 2-year perspective with all convergence criteria and other conditions of membership in the eurozone. Less attention was paid to potential dates, and more attention to the conditions for secure joining the eurozone. Such was the spirit of the aforementioned document of 2010, emphasizing the uncertainty arising from the global economic crisis and the Greek crisis. Therefore, the authors of the document paid special attention to the balance of benefits and losses and the conclusions reached from both crises for the Polish strategy of joining the EMU.

In a similar tone, began to speak about the possibility of Poland's accession to the EMU the contemporary Minister of Finance - J. Rostowski and the President of the National Bank of Poland - M. Belka, earlier supporters of the rapid adoption of the single currency. Both politicians began to stress the need for solid preparation of the Polish economy for membership in the EMU, so that it would bring more benefits than loses after adopting euro. Over time, when the crisis in the eurozone exposed more and more its structural weaknesses, Rostowski and Belka suggested postponing Poland's membership in EMU until the construction of the reformed eurozone was safe enough for Poland to enter it (Chądzyński, Godusławski, 2018). This was also clearly confirmed by the document prepared by the Ministry of Foreign Affairs setting out the priorities of Polish foreign policy for years 2012-2016, in which it was stated that Poland's accession to the eurozone would only be possible when conditions within the zone are stabilized, and Poland is prepared in macroeconomic and legal terms (Priorities, 2012, p. 8).

On the one hand, the eurozone crisis has weakened the pace of Poland's accession to the EMU, but on the other hand it has contributed to increasing Poland's activity in the European forum. Faced with a number of management reforms in the eurozone, the ruling team at the time considered as the overarching goal to create such a cooperation architecture that would not deepen the division between countries that adopted the single currency and those outsider the eurozone. Poland aimed at having a real impact on the changes taking place in EMU, which is why it advocated that anti-crisis measures to be taken by all EU member states, not just by the eurozone. President B. Komorowski claimed that the goal of our diplomacy is to participate even before joining the EMU in making decisions healing the eurozone, because in the future we plan to join it. The greatest successes of the then government included, first of all, obtaining the observer

${ }^{5}$ As Wawrzyniec Michalczyk writes, if one could infer from the experience of years 2008-2010, the course of volatility of the relation between euro and zloty was so unstable that maintaining the exchange rate within even the widest possible range of $+/-15 \%$ would probably be impossible. 
status in the European Stability Mechanism providing financial support to eurozone countries; ${ }^{6}$ and secondly, the adoption by the European Union countries of the package of six documents (the so-called six-pack) contributing to increased budgetary discipline in all EU Member States; and thirdly, negotiating and signing on March 2, 2012 the Treaty on Stability, Coordination and Governance in the Economic and Monetary Union, commonly known as the fiscal pact. It granted Poland and other countries which had not adopted the single currency the right to participate in the meetings of the summit of the eurozone countries dealing with the competitiveness of the signatories of the fiscal pact, changes in the overall structure of the eurozone and the basic rules for the eurozone that will apply in the future as well as the implementation of the provisions of the fiscal pact. ${ }^{7}$

The above activities of the contemporary government in the realities of the crisis in the eurozone certainly ensured Poland's participation in the central European integration developments. They were a clear signal of the extension of Poland's path to the EMU membership, with the simultaneous intention of active participation in modernizing the eurozone for the benefit of all European Union countries.

\section{Poland's policy towards membership in the EMU during the PiS rule}

The Law and Justice party (PiS) has been co-creating the government twice since Poland's accession to the EU. For the first time in the period starting from October 2005 till November 2007 with such groups as the Self-Defence (Samoobrona RP) and the League of Polish Families (Liga Polskich Rodzin). For the second time, starting from November 2015 till today (July 2019) - in the coalition with the Jarosław Gowin's Agreement (Porozumienie Jarosława Gowina) and Zbigniew Ziobro's Solidary Poland (Solidarna Polska). Although the views of PiS supporters do not sympathize with Poland's membership in the eurozone, their radicalization is also becoming noticeable. In addition, no government documents were published in any of the above periods indicating conducting works on entering by Poland the EMU.

In 2005-2007, the ruling team had opposite views to their predecessors (the M. Belka government), who were in favour of the rapid adoption of the single currency. None of the two governments at the time - lead by Kazimierz Marcinkiewicz and J. Kaczyński, pursued the policy aimed at Poland's membership in the eurozone based on the strategy adopted at the government level. The discussion in this matter was basically limited to the abstemious declarations by several politicians, from which it resulted that the then ruling team did not explicitly reject the adoption of the euro, but postponed this moment to an indefinite future. In November 2005, the newly elected Prime Minister Kazimierz Marcinkiewicz said that in the forthcoming parliamentary term there is no need for Poland to enter the eurozone. Zyta Gilowska, who at various times in the years 2005-2007

${ }^{6}$ Pursuant to point (9) of the preamble of the Treaty establishing the European Stability Mechanism, countries from outsider The eurozone may participate as observers at the meetings discussing support for eurozone countries, with the right of access to information and consultations. See: Treaty Establishing the European Stability Mechanism, www.esm.europa.eu, 23.07.2019.

7 Article 12 (3) of the Treaty on Stability, Coordination and Governance in the Economic and Monetary Union, www.consilium.europa.eu. 
held the office as the Minister of Finance in the governments of Kazimierz Marcinkiewicz and Jarosław Kaczyński, treated the adoption of the single currency by Poland as complementing its the membership in the European Union. She believed that in 2009 Poland should reach the state of readiness in the macroeconomic sense, however, she emphasized the need not only to meet the convergence criteria, but above all to be able to maintain them in the long term. She agreed on this issue with J. Kaczyński, who was then the Prime Minister, and was of the opinion that Poland has to introduce euro, but can do it only when the level of economic development of Poland and the EU countries is similar (Stasiuk, 2006).

Lech Kaczyński, who was the President of the Republic of Poland in years 20052010, was not a supporter of the quick adoption of the single currency. He pushed the idea of holding a referendum that would decide about joining by Poland's the eurozone and should precede the possible constitutional change. The proposal to hold the referendum seems to have been a means to prolong the discussion on Poland's accession to the EMU, convenient for PiS governments, but already burdensome for the PO-PSL coalition preparing Poland to replace the zloty with the euro in 2012 which was not providing for the possibility of organizing the referendum in the Road Map. The idea aroused a lot of controversy, because Poles, agreeing to join the European Union in the referendum held on June 7-8, 2003, also agreed to the adoption of the single currency. So, natural questions was posed, what would the referendum on the euro be about? President L. Kaczyński replied that the question formulated in the referendum should refer to the date, because he agreed that Poland's membership in the EMU resulted from the accession treaty, but he considered 2012 as a very bold proposal of the PO-PSL government. Among the working proposals the question was formulated: „Do you want to give up zloty, give up the sovereign monetary policy of the Polish state and enter into the eurozone, for example in the years 2012-16? ” or ,Do you agree for The introduction of euro in 2012?" (Kaczyński, 2008; Grochal, Wroński, 2009).

The economic crisis in the eurozone naturally devaluated the imperative of holding the referendum, and the significant victory of PiS in the 2015 parliamentary elections gave this party legitimacy to implement the election program negatively referring to the adoption of the single currency. This was not new, but it is noteworthy to point to the above-mentioned radicalization of the ruling party's views on this issue. The justification for this thesis stems from the comparison of the PiS election program from 2004 and 2014. In the 2004 program, the negative position regarding Poland's entry into the eurozone was economically substantiated and fit into the discussion presenting arguments for and against adopting euro. According to PiS, the rapid introduction of euro will put Polish economy under too much competitive pressure from the eurozone economies and big EU enterprises which are strong on the world markets, and have been prepared for competition on those markets for decades. It will also definitely weaken the competitiveness of Polish exports. At the same time, the election program emphasized the need for the independent and stable monetary policy, which clearly excluded membership in the EMU based on the single monetary policy. The main conclusion was that PiS would be opposed to introducing the single currency in Poland until the costs of monetary integration are much lower than the potential benefits (IV Republic, 2005, pp. 62-63). 
In the 2014 program, PiS no longer presented the reasons for the negative position on the adoption of euro, but clearly indicated that it would maintain the national currency - the Polish zloty, being guided by the Polish raison d'etat, national interests and economic considerations related to the development. It considered all the projects of the quick introduction of euro not only a political mistake, but also a manifestation of the Lack of responsibility of politicians ruling Poland. What's more, the program included a clear declaration of taking effective measures to shape the conditions of Polish membership in the EU, which would retain and, where necessary, restore the primacy of Polish strategic interests. This applied in particular to maintaining the zloty and its subjectivity as the Polish national currency (The Law, 2014, pp. 157-158 ).

The decision of the Council of Ministers, led by Prime Minister Beata Szydło, liquidating the office of the Government's Representative for introduction of the euro by the Republic of Poland on January 1, 2016, as well as dissolving National Coordination Committee for the euro, the Coordination Council and the Interinstitutional Working Team for the preparation of the introduction of the euro by the Republic of Poland on January 27, 2016, fitted the PiS approach very aptly. ${ }^{8}$ The liquidation of the institutional structure responsible for the comprehensive preparation of Poland for the adoption of euro was a clear signal by PiS government of not taking any steps to bring Poland closer to the EMU in the near future. ${ }^{9}$ In the same way, the open letter from Polish economists to Prime Minister Mateusz Morawiecki from early 2018 was commented, which was calling for the resumption of preparations for Poland's entry into the eurozone. The head of the Chancellery of the Prime Minister, Michał Dworczyk, said merely that there are no works being carried out on Poland's accession to the Eurozone (Bodalska, 2018). According to PiS chairman and mastermind - J. Kaczyński and the prime ministers Beata Szydło and M. Morawiecki, maintaining the zloty lies in the Polish national interest. According to them it contributes, among others to a higher GDP growth rate in Poland than in Europe, which was highest since 2007 and in 2018 amounted to $5.1 \%$, in the EU - 1.9\% (Convergence, 2019, p. 157-158). The same opinion is expressed by the Head of the NBP, Adam Glapiński, who noticed that we are experiencing a real economic miracle in Poland, and the stable growth and lack of imbalance, ,is not a coincidence and we owe it primarily to having our own currency, which allows conducting independent monetary policy and fiscal policy which is nonsubordinated to the orders of others countries" (Glapiński, 2019). What's more, he announced that regardless of who will rule in the country, as long as he is the president of the NBP, Poland will not enter the ERM II or the eurozone. In addition, PiS politicians have repeatedly emphasized that the adoption of the single currency will be possible when Poland reaches the level of GDP and living standards very similar to those of

${ }^{8}$ See: Regulation of the Council of Ministers of December 28, 2015 regarding the abolition of the Government's Representative for introduction of the euro by the Republic of Poland, Journal of Laws of 2015, item 2352; Regulation of the Council of Ministers of January 15, 2016 on the abolition of the National Coordination Committee for Euro, the Coordination Council and the Interinstitutional Working Team for the preparation of the Republic of Poland for the introduction of euro by, Journal of Laws of 2016, item 117.

9 The Ministry of Finance website includes the entry on not continuing works on preparations for the introduction of euro and the availability of publications and scientific analyzes regarding Poland in the EMU on the Ministry's archival page. 
Germany. Otherwise, Poland would be threatened by increase in prices and economic stagnation.

\section{Conclusions}

The analysis of perception by the political parties of the issue of Poland's membership in the EMU since 2004 presented in the text shows the evolution of views from euphoria, through restraint, to reluctance or even negation of the adoption of the common currency.

Poland's accession to the European Union was a great success of Polish diplomacy, and even though the foundations of the world economy were shaken for the first time (after the attacks on the World Trade Centre in 2001), the eurozone was developing without major problems, gradually expanding the group of member countries. Poland's accession to the EMU, after meeting the convergence criteria, seemed a natural consequence of joining the European Union. At that time, the ruling elite did not ask whether to enter the eurozone, but when to do it and according to what scenario. In the political and economic debate various dates of Poland's potential accession to the EMU and ways of joining the single currency were given, ranging from the rapid stabilization of the zloty with the ERM II mechanism and compliance with the convergence criteria during the 2-year presence in the fluctuation band, to the prior fulfilment of the requirements of the EMU membership and subsequent incorporation of the zloty into the ERM II for the period of two years, in order to check the sustainability of meeting the convergence criteria. Government of M. Belka, which was ruling the country for a short period of time, and subsequent governments of D. Tusk clearly indicated that Poland's membership in the EMU is a strategic goal of Polish policy bringing more benefits than losses.

The global economic crisis and the subsequent crisis in the eurozone verified the views of the ruling elite. They also changed the attitude of Polish society to the adoption of the euro. The common currency enjoyed the greatest support among Poles in 2002 (before joining the EU), when $64 \%$ of the population were in favour of adopting it. After joining the European Union, the acceptance of Poles deteriorated, and in 2007-2008 the percentage of supporters and opponents of adopting euro was similar. In the first quarter of 2009, following Slovakia's accession to the EMU and during the discussion on the adoption of the euro in Poland, public support increased to 52-53\% (Concerns, 2013, p. 3,). Upon the disclosure of information of the economic problems of Greece and the eurozone, Poles' support for adopting the single currency began to decline. The latest Communique on the Research conducted by the Polish Public Opinion Research Centre (CBOS) in April 2017 on European issues shows that as many as 74\% of adult Poles are currently opposed to joining the EMU. At the same time, the lowest percentage of supporters of adopting the euro is being recorded, amounting to only $22 \%$ of respondents (What Union, 2017, p. 10).

The crisis of the eurozone has exposed a number of its weaknesses. Although the rescue efforts undertaken by European countries were multidimensional in their nature, strengthening budgetary, economic, financial and banking system cooperation, the economic problems of the eurozone combined with the migration crisis (since 2014) have 
undoubtedly contributed to the increase of radical tendencies in Europe and in Poland. They have become the main reason why the strategic goal of the ruling elite is currently non-entering by Poland the single currency system. Thus, the research analysis carried out in the text confirms the hypothesis specified in the introduction to the article.

The views of the currently ruling party (PiS) on the adoption of the euro are also radicalizing and according to them non-entering the eurozone will contribute to Poland's economic growth, to the contrary - it is the Polish currency that is building the strength of Polish economy. Arguments of the ruling party about rising prices, economic stagnation, the need for Poland to match its wealth and pay rates to the richest EU countries are getting to Poles, the vast majority of whom oppose the adoption of the euro.

Despite the treaty obligations, it is possible to remain outside the EMU, just taking into account the example of Sweden, which, without having the opt-out clause, does not belong to the eurozone because it knowingly does not meet one of the convergence criteria, i.e. the membership in the ERM II. Is the Swedish variant a good solution for Poland in the current political reality? Yes, provided that, first of all, Poland will treat the fulfilment of other convergence criteria as a determinant of macroeconomic policy and not as a brake on excessively flexible financial policy. Secondly, it will respect European values and principles and cooperate with the EU in matters important to it (e.g. migration policy). Thirdly, it will be a country actively and constructively supporting the development of the eurozone and the European Union itself. Then it will have a chance to influence changes that may occur in the eurozone, in particular during the new term of office of the European Commission and the European Parliament. Unfortunately, the realities are that in the first quarter of 2019 Polish debt was growing quicker than GDP and although it remains within legally permissible limits, this trend indicates a growing threat to the state's finances in the future (Frączyk, 2019). The possibilities of political influencing by the ruling party the reforms within the eurozone are also unreal. No one will allow a country outside the eurozone, which is subject to the rule of law infringement procedure, joining the discussion on the possibility of creating the common budget for the eurozone, the appointment of the European minister of finance or the parliament of the eurozone states. Therefore, maintaining the current trend in the European integration policy of the current ruling elite may lead Poland to marginalization within the European Union.

\section{Bibliography}

Attack on zloty (2009), "Wprost 24", no. 7, www.wprost.pl.

Bodalska B., Poland for the time being without hope for joining the eurozone, www.euractiv.pl, 05.01.2018.

Bratkowski A., Rostowski J. (2001), Why does unilateral euroization make sense in the case of Poland and (some) other candidate countries?, "Bank i Kredyt", no. 11-12.

Chądzyński M., Godusławski B. (2018), What an economist thinks, that is the change of views of Tusk, Rostowski, Szczurek, "Biznes. Gazeta Prawna" of 12.05.2018, www.biznesgazetaprawna.pl.

Concerns and hopes related to the introduction of the euro in Poland (2013), CBOS Communique on the Research, Warsaw, March, www.cbos.pl.

Convergence Program. Update 2019, Republic of Poland, www.ec.europa.eu, 27.07.2019. 
Determinants of the implementation of subsequent stages of the Road Map of the adoption by Poland the euro, the Ministry of Finance, The Government's Representative for introduction of the Euro by the Republic of Poland, Warsaw, April 2009, www.mf-arch2.mf.gov.pl.

Donald Tusk's Exposé from November 23, 2007, www.bankier.pl.

Frączyk J., Polish debt is growing faster than GDP, www.money.pl, 19.09.2019.

Glapiński A., Polish zloty is a strong Polish economy, inaugural speech during the NBP conference entitled ,Zloty, euro and the Polish cause” organized on May 22, 2019 in Warsaw, www.nbp.pl.

Grochal R., Wroński P., President again from PiS, "Gazeta Wyborcza” of 28.02.2009, www.gazetawyborcza.pl, 23.07.2019.

IV Republic. Justice for All, Law and Justice, Program 2005, www.old.pis.org.pl, 24.07.2019.

Kaczyński L: first the referendum on euro, then the change to the constitution, Polish Press Agency of 31.10.2008, www.pb.pl, 23.07.2019.

Kołodziejczyk K. (2012), Poland's Cooperation with International Financial Institutions, in: Poland's Participation in International Organizations, eds. I. Rysińska, S. Parzymies, Wydawnictwo Scholar, Warsaw.

Maciejewicz P., Kołodko: may tie zloty against euro, “Gazeta Wyborcza” of 17.07.2002, www.wyborcza.pl, 19.07.2019.

Michalczyk W. (2013), Determinants of zloty to euro exchange rate in view of joining the ERM 2 mechanism, www.knfpan.pan.pl/images/Finanse_6_4-W.Michalczyk2.pdf, no. 1.

Priorities of Polish foreign policy 2012-2016 (2012), Ministry of Foreign Affairs Warsaw, www.msz. gov.pl.

Road Map of the adoption by Poland the euro, 28.10.2008, Ministry of Finance, www.mf-arch2.mf. gov.pl.

Stasiuk T. (2006), Gilowska on Poland's readiness to adopt euro, "Puls Biznesu" of 30.11.2006, www.pb.pl, 24.07.2019.

The Law and Justice Program 2014, www.old.pis.org/dokumenty, 24.07.2015.

What Union do Poles Want (2017), Communication from CBOS research, Warsaw, April, www.cbos.pl.

\section{Polska polityka wobec czlonkostwa w unii gospodarczo-walutowej}

\section{Streszczenie}

Wejście Polski do Unii Europejskiej determinuje przyszłe członkostwo w unii gospodarczo-walutowej (UGW). Przedmiotem badań jest analiza polskiej polityki wobec członkostwa w UGW w okresie pierwszych 15 lat członkostwa Polski w UE. Przeprowadzone badania mają charakter politologiczny i celowo nie koncentrują się na ekonomicznych korzyściach i wyzwaniach członkostwa w UGW.

Celem badań jest ukazanie zmian zachodzących w polityce wobec członkostwa Polski w UGW prowadzonej przez partie rządzące, kolejno przez koalicję Platformy Obywatelskiej i Polskiego Stronnictwa Ludowego (PO-PSL) w latach 2007-2015 i następnie przez Prawo i Sprawiedliwość (PiS) w latach 2005-2007 w porozumieniu z Samoobroną oraz Ligą Polskich Rodzin oraz 2015-2019 w koalicji z Porozumieniem Jarosława Gowina i Solidarną Polską Zbigniewa Ziobro.

Główne pytania badawcze dotyczą tego w jaki sposób postrzegały członkostwo Polski w UGW partie rządzące począwszy do 2004 r. oraz co sprawiło, że jeszcze niedawno dołączenie do strefy euro w Polsce było celem strategicznym elity rządzącej, a współcześnie celem strategicznym stało się niewchodzenie do UGW.

Głównymi metodami badawczymi były analiza zawartości treści dokumentów oraz metoda porównawcza. Pierwsza metoda pozwoliła na przedstawienie perspektywy wejścia Polski do strefy euro od strony polityki partii rządzących. Dlatego tekst powstał głównie na podstawie materiałów źródłowych, 
tj. raportów, dokumentów rządowych, wystąpień polityków, programów wyborczych partii oraz artykułów prasowych. Druga metoda badawcza pozwoliła na porównanie koncepcji członkostwa Polski w UGW prezentowanych w różnych programach rządzących partii politycznych.

Wynik przeprowadzonych badań wskazuje na radykalizację poglądów polskiej sceny politycznej. Dowodzi także tego, że data przyjęcia wspólnej waluty zależeć będzie nie tylko od spełnienia kryteriów konwergencji, ale także od tego, która opcja polityczna będzie rządziła w Polsce.

Słowa kluczowe: polskie partie polityczne i euro, członkowstwo w UGW, radykalizacja 